\title{
Deodorizing Effects of Phlorotannins from Edible Brown Alga Eisenia bicyclis on Methyl Mercaptan
}

\author{
Do-Hyeong Kim ${ }^{1}$, Sung-Hwan Eom ${ }^{1}$, Tae Hoon $\mathrm{Kim}^{2}$, Bong-Yun Kim ${ }^{3}$, Young-Mog Kim ${ }^{1} \&$ Seon-Bong Kim ${ }^{1}$ \\ ${ }^{1}$ Department of Food Science and Technology, Pukyong National University, Busan, Korea \\ ${ }^{2}$ Department of Herbal Medicinal Pharmacology, Daegu Haany University, Gyeongsangbuk-do, Korea \\ ${ }^{3}$ MS Bio Co., LTD., Busan, Korea \\ Correspondence: Seon-Bong Kim, Department of Food Science and Technology, Pukyong National University, \\ Busan, Korea. Tel: 82-51-629-5827. E-mail: owlkim@pknu.ac.kr
}

Received: September 10, 2012 Accepted: October 8, 2012 Online Published: December 13, 2012

doi:10.5539/jas.v5n1p95 URL: http://dx.doi.org/10.5539/jas.v5n1p95

\begin{abstract}
In search for new deodorizing compounds, we were identified three phlorotannins; eckol (1), dioxinodehydroeckol (2) and dieckol (3) from edible brown seaweed Eisenia bicyclis and characterized by Fast-atom bombardment mass spectrometry (FAB-MS) and nuclear magnetic resonance (NMR). The deodorizing activity of those compounds was evaluated against methyl mercaptan, which is well known as a major causative material of halitosis and off-flavor. Among them, compound $\mathbf{3}$ exhibited the highest deodorizing activity against methyl mercaptan at the $\mathrm{IC}_{50}$ values of $26.71 \pm 4.16 \mu \mathrm{g} \mathrm{mL}^{-1}$, followed by compound $2(40.57 \pm$ $\left.0.63 \mu \mathrm{g} \mathrm{mL}^{-1}\right)$ and compound $1\left(43.62 \pm 1.52 \mu \mathrm{g} \mathrm{mL}{ }^{-1}\right)$. Thus, these results suggest that the phlorotannins derived from E. bicyclis can be an effective deodorizing constituent in the food industry and pharmaceutical industries.
\end{abstract}

Keywords: deodorizing activity, Eisenia bicyclis, methyl mercaptan, phlorotannins

\section{Introduction}

Volatile sulfide compounds (VCSs) such as hydrogen sulfide, dimethyl sulfide, and methyl mercaptan have been known as major compounds causing off-flavor from foods and the industrial sites (Tanabe et al., 2012). It is generated through an enzymatic modification of sulfur containing amino acids (cysteine and methionine), which are made available following proteolytic degradation of proteins (Hughes \& McNab, 2008; Ali \& Nozaki, 2007). The tongue coating consists of desquamated epithelial cells, food debris, bacteria and salivary protein, which provide all the elements for production of volatile sulfide compounds and cause halitosis from the mouth (Gnanasekhar, 2007; Youngnak-Piboonratanakit and Vachirarojpisan, 2010). It has been also known that there is a highly positive correlation between the concentration of methyl mercaptan and the generation of halitosis (Kim et al., 2010; Richter, 1996). Since VSCs are the major causes of the malodor, suppression in production of the VSCs is an effective strategy to prevent the oral malodor. (Du et al., 2012; Sanz et al., 2001) Recently, there has been a growing interest in investigating natural plant extracts as efficacious and safe substances for oral care. More specifically, natural plant extracts such as thyme, rosemary, tea, marine algae, mongolian bark and sage has shown potent qualities as a natural anti-halitosis ingredient (Lourith \& Kanlayavattanakul, 2010; Dodds et al., 2009; Lee et al., 1999). Although the function mechanism of the deodorizing effect of phlorotannins has not been unclear, it is assumed that the mechanism of the deodorant action of phenolic compounds in natural extracts is that these compounds are oxidized by oxygen in the atmosphere to form a highly reactive quinone structure (Hiramoto et al., 2001). It is considered that methylmercaptan might relate to the conversion of phenolic hydroxyl group into quinone and the subsequent formation of thio ether with benzene ring due to the nucleophilic addition of methylthio group (Hiramoto et al., 2006).

Among marine algae, edible brown seaweeds have been identified as a potential deodorizer that may be useful in the food industry (Kim et al., 2008). Furthermore, brown algae contain various minerals and dietary fiber, brown algae are widely eaten in East asia. Brown algae such as Eisenia bicyclis, Ecklonia stolonifera, E. cava, and Hizikia fusiformis were reported to contain a high amount of phlorotannins. Phlorotannins, the polymerization of phloroglucinol, are called seaweed polyphenol (Kim et al., 2006; Ragan \& Glombitza, 1986). According to 
recent reports, phlorotannins have known to possess a variety of physiological activities such as antioxidation (Kang et al., 2005; Kang et al., 2007; Zou et al., 2008; Yoon et al., 2011; Eom et al., 2011a), antidiabetic effects (Eom et al., 2012b; Okada et al., 2004), antidementia (Yoon et al., 2008), antimicrobial activity (Eom et al., 2011b), anti-coagulant activity (Jeong et al., 2009), anti-inflammatory activity (Kang et al., 2012), anticonvulsant, and sleep inducer (Cho et al., 2012).

However, it has not been investigated on deodorizing activity of isolated compounds from edible brown algae against methyl mercaptan. Therefore, in this study, we isolated its active compounds from E. bicyclis and investigated their effect against methyl mercaptan associated with halitosis.

\section{Materials and Methods}

\subsection{Materials}

E. bicyclis was gathered at Ulleung Island, Korea on September 2010, washed in fresh water to remove undesirable materials. Dried E. bicyclis was ground and then finely powdered with a food mixer (HMF-1000A; Hanil Electronics, Seoul, Korea). The ground powder was stored at $4^{\circ} \mathrm{C}$ until use. All reagents used in this study were analytical grade.

\subsection{Preparation of Standard Methyl Mercaptan Solution}

Two $\mathrm{mL}$ of authentic methyl mercaptan $\left(1 \mu \mathrm{g} \mu \mathrm{L}^{-1}\right)$ in benzene (Wako Pure Chem., Osaka, Japan) was dissolved in $198 \mathrm{~mL}$ of ethanol to be kept at $-70^{\circ} \mathrm{C}$ in a deep-freezer (Samwon Freezing Engineering Co., Busan, Korea). The solution was then diluted to $1 \mu \mathrm{g} \mathrm{mL}^{-1}$ in distilled water to be used for assay of deodorizing activity.

\subsection{Determination of Total Phenolic Compounds}

The total phenolic contents was determined by the method of Folin-Ciocaleu with slight modifications (Waterman and Mole, 1994). One hundred $\mathrm{mL}$ of dilluted sample and $0.5 \mathrm{~mL}$ of $1 \mathrm{~N}$ Folin-Ciocalteu reagent (Sigma Co., St. Louis, USA) were put in the eppendorf tube and mixed up. The solution was incubated for 3 min at room temperature and then added to $0.4 \mathrm{~mL}$ of $7.5 \% \mathrm{Na}_{2} \mathrm{CO}_{3}$. the mixture was allowed to stand for $90 \mathrm{~min}$ in a darkroom at room temperature and then centrifuged at $1,600 \times \mathrm{g}$ for $8 \mathrm{~min}$. After centrifugation process, the supernatant was measured in terms of optical density at $765 \mathrm{~nm}$ by using a GENios ${ }^{\circledR}$ microplate reader (Tecan Austria GmbH; Grödig, Austria). The concentration of the total phenolic contents were calculaed using a calibration curve of phloroglucinol (Sigma Co., St. Louis, USA). Total phenolic contents was calculated using the linear equation from a calibration curve and expressed as $\mathrm{mg}$ phloroglucinol equivalent (PGE)s g ${ }^{-1}$ of dry weight.

\subsection{Deodorizing Activity Assay}

Deodorizing activity was evaluated by the method of Tokita et al (1984) with slight modifications. Sample $(0.1$ $\mathrm{mL}$ of different concentrations) and $0.9 \mathrm{~mL}$ of $0.2 \mathrm{M}$ potassium phosphate buffer $(\mathrm{pH} 7.5)$ were put in the $30 \mathrm{~mL}$ of vial, and added $1 \mathrm{~mL}$ of standard methyl mercaptan solution $\left(1 \mu \mathrm{g} \mathrm{mL} L^{-1}\right)$. The vial was immediately sealed up and agitated with a Vortex mixer (Vortex GENIE 2; Scientific industries, Inc., Bohemia, USA) for 5 sec, and then incubated for $6 \mathrm{~min}$ at $37^{\circ} \mathrm{C}$. The methyl mercaptan was liberated into the headspace of the vial was extracted with a gas tight syringe ( $250 \mu \mathrm{L}$ SYR; Hamilton Co., Reno, USA) and then analyzed with a gas chromatography (GC; HP model 5890, Hewlett-Packard Co., Palo Alto, USA) equipped with a flame photometric detector. Operating conditions of GC are as follows; HP-1 column $(5 \mathrm{~m} \times 0.53 \mathrm{~mm} \times 2.65 \mu \mathrm{m}$; Hewlett-Packard Co., Palo Alto, CA), column temperature $\left(35^{\circ} \mathrm{C}\right)$, injector temperature $\left(150^{\circ} \mathrm{C}\right)$, and detector temperature $\left(200^{\circ} \mathrm{C}\right)$. Nitrogen was used as carrier gas at a flow rate of $30 \mathrm{~mL} \mathrm{~min}^{-1}$. Deodorizing activity was expressed as the decreased amount of methyl mercaptan and was calculated using the equation:

$$
\text { Deodorizing activity }(\%)=1-\frac{\text { sample }}{\text { control }} \times 100
$$

Furthermore, deodorizing activity was expressed as $\mathrm{IC}_{50}\left(50 \%\right.$ inhibitory concentration). $\mathrm{IC}_{50}$ values were calculated by linear regression analysis of deodorizing activity. All determinations were performed in triplicate.

\subsection{Extraction and Isolation of Deodorizing Components}

One $\mathrm{kg}$ of powdered E. bicyclis were putted into $10 \mathrm{~L}$ of methanol, and then refluxed for $3 \mathrm{~h}$ at $70^{\circ} \mathrm{C}$. The process was 3 times repeated to get the extracts and the resulting methanol extract (147.62 g) was obtained by means of the vacuum evaporation. These extracts were dissolved in $1 \mathrm{~L}$ of water and transferred into a separating funnel. The solution was treated with $n$-hexane $(1.0 \mathrm{~L} \times 3)$, and consecutively followed by dichloromethane $(\mathrm{DCM})(1.0 \mathrm{~L} \times 3)$, by ethyl acetate $(\mathrm{EtOAc})(1.0 \mathrm{~L} \times 3)$ and by $n$-butanol $(1.0 \mathrm{~L} \times 3)$. Finally, the $n$-hexane 
(41.21 g), DCM (1.89 g), EtOAc (41.70 g), n-butanol (25.80 g), and water -soluble fraction (46.43 g) were obtained, respectively. The EtOAc-soluble fraction $(20.29 \mathrm{~g})$ exhibiting the most effective deodorizing activity of these extracts was loaded on Sephadex LH-20 column $(4.0 \mathrm{~cm} \times 50 \mathrm{~cm}$; GE healthcare, Stockholm, Sweden $)$ and eluted with $100 \%$ methanol. The eluates from column chromatography were loaded on Kieselgel $60 \mathrm{~F}_{254}$ TLC plates ( $0.25 \mathrm{~mm}$ layer thickness; Merck, Darmstadt, Germany). Detection was performed with UV-lamp (254, $365 \mathrm{~nm}$, ENF-260C; Spectroline Co., Westbury, USA) after spraying of 10\% sulfuric acid in methanol. Among of 8 sub-fractions (EF01-EF08) detected in this study, sub-fraction EF02 was loaded on LiChroprep RP-18 column $(1.1 \mathrm{~cm} \times 37 \mathrm{~cm}$; Merck, Darmstadt, Germany) and eluted with $20 \%$ to $100 \%$ methanol. The eluates were repetitively performed by column chromatography on Sephadex LH-20 $(1.2 \mathrm{~cm} \times 38 \mathrm{~cm})$ with methanol. Compound $1(49.48 \mathrm{mg})$ was isolated from the sub-fraction EF02. The sub-fraction EF06 was further separated by column chromatography on LiChroprep RP-18 column $(1.1 \mathrm{~cm} \times 37 \mathrm{~cm})$ and successive Sephadex LH-20 column $(1.2 \mathrm{~cm} \times 38 \mathrm{~cm})$, and compound $2(15.41 \mathrm{mg})$ and compound $3(26.72 \mathrm{mg})$ were isolated. The isolated compounds were identified by comparisons of their physicochemical and spectroscopic data $\left({ }^{1} \mathrm{H},{ }^{13} \mathrm{C}\right.$ NMR, 2D NMR, and MS) with those of authentic samples and reference data (Kang et al., 2003; Okada et al., 2004).

\subsection{Instrumental Analysis}

Varian VNS600 instrument (Varian, Inc., Walnut Creek, USA) was used for ${ }^{1} \mathrm{H}$ and ${ }^{13} \mathrm{C}$ NMR, which was measured at 600 and $150 \mathrm{MHz}$, respectively. The chemical shifts were expressed in parts-per-million (ppm); and DMSO- $d_{6}\left(\delta_{\mathrm{H}}=2.49 ; \delta_{\mathrm{C}}=39.7\right)$ was used as solution; and tetramethylsilane as standard material. The $J_{C H}$ value was est at $8 \mathrm{~Hz}$ in the heteronuclear multiple-bond correlation spectroscopy spectra. Fast-atom bombardment mass spectrometry (FAB-MS) was measured by means of orthogonal acceleration time-of-flight (oaTOF) spectrometer (AutoSpec; Micromass UK, Ltd., Manchester, UK), by using 3-nitrobenzyl alcohol.

\subsection{Statistical Analysis}

All results were indicated as mean \pm S.E.M (standard error of the mean) $(n=3)$ and the analysis of variance (ANOVA) was used to make a multiple comparison. SPSS v12.01 (SPSS, Chicago, USA) was used to conduct ANOVA and the difference in statistical significance was estimated by Duncan's Multiple Range tests $(P<0.05)$.

\section{Results}

\subsection{The Deodorizing Activity against Methyl Mercaptan of E. bicyclis Extracts}

As shown in Table 1, the deodorizing activities of E. bicyclis methanol extracts and its soluble extract against methyl mercaptan were evaluated. It was revealed that the EtOAc-soluble extract was the highest deodorizing activity exhibiting $\mathrm{IC}_{50}$ value of $77.49 \pm 0.75 \mu \mathrm{g} \mathrm{mL}-1$, followed $n$-butanol $\left(278.98 \pm 19.87 \mu \mathrm{g} \mathrm{mL}^{-1}\right)$, DCM $\left(307.90 \pm 5.83 \mu \mathrm{g} \mathrm{mL}^{-1}\right), n$-hexane $\left(733.95 \pm 30.77 \mu \mathrm{g} \mathrm{mL}^{-1}\right)$, and water $\left(1,256.16 \pm 54.20 \mu \mathrm{g} \mathrm{mL}^{-1}\right)$-soluble extracts. The $\mathrm{IC}_{50}$ values of the EtOAc, $n$-butanol and DCM -soluble extracts were estimated to possess about 2 times to 8 times more strong deodorizing activity than sodium copper chlorophyllin, which is most widely known as a deodorant for halitosis. Lee et al (1999) reported that deodorizing activity of benxethonium, sodium fluoride, and cetylpyridinium chloride, which are used as the inhibitors of halitosis and antibacterial ingredients for commercial mouthwashes, against methyl mercaptan was less than $50 \%$ at concentration of $5 \mathrm{mg} \mathrm{mL}^{-1}$.

Table 1. Deodorizing activities of Eisenia bicyclis methanol extracts and its soluble extracts

\begin{tabular}{cc}
\hline Solvent fractions $^{\dagger}$ & $\mathrm{IC}_{50}{ }^{*}$ value $\left(\mu \mathrm{g} \mathrm{mL}^{-1}\right)$ \\
\hline Methanol & $241.52 \pm 6.96$ \\
$n$-Hexane & $733.95 \pm 30.77^{\mathrm{a}}$ \\
DCM & $307.90 \pm 5.83^{\mathrm{b}}$ \\
EtOAc & $77.49 \pm 0.75^{\mathrm{c}}$ \\
$n$-Butanol & $278.98 \pm 19.87^{\mathrm{d}}$ \\
Water & $1,256.16 \pm 5.42^{\mathrm{e}}$ \\
Sodium copper chlorophylline & $605.13 \pm 17.64$ \\
\hline
\end{tabular}


${ }^{*} \mathrm{IC}_{50}$ value was defined as the concentration of inhibitor required to inhibit $50 \%$ of deodorizing activity. Different letters (a, b, c, d, e) indicate significant differences at the level of $P<0.05$.

${ }^{\dagger}$ DCM, dichloromethane; EtOAc, ethyl acetate

Moreover, the total phenolic contents in each extract showed in accordance with the results of deodorizing activity against methyl mercaptan. As shown in Table 2, the EtOAc-soluble extract $(767.78 \pm 15.46 \mathrm{mg} \mathrm{mg}$ PGEs $\mathrm{g}^{-1}$ ), which exhibits the highest deodorizing activity, had the highest total phenolic contents, followed by the DCM (434.17 $\pm 16.08 \mathrm{mg}$ PGEs g $\left.^{-1}\right), n$-butanol $\left(343.80 \pm 19.18 \mathrm{mg}\right.$ PGEs g $\left.{ }^{-1}\right), n$-hexane $(278.89 \pm 7.14 \mathrm{mg}$

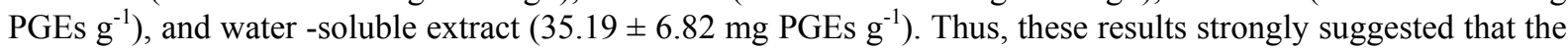
total phenolic contents of E. bicyclis are closely related with the deodorizing activity.

Table 2. Total phenolic contents of Eisenia bicyclis methanol extracts and its soluble extract

\begin{tabular}{ll}
\hline Solvent fractions $^{\dagger}$ & Total phenolics $\left(\mathrm{mg} \mathrm{PGE}^{\mathrm{a}} \mathrm{g}^{-1}\right.$, dry basis $)$ \\
\hline Methanol & $332.96 \pm 10.92$ \\
$n$-Hexane & $278.89 \pm 7.14^{\mathrm{d}}$ \\
DCM & $434.17 \pm 16.08^{\mathrm{b}}$ \\
EtOAc & $767.78 \pm 15.46^{\mathrm{a}}$ \\
$n$-Butanol & $343.80 \pm 19.18^{\mathrm{c}}$ \\
Water & $35.19 \pm 6.82^{\mathrm{e}}$
\end{tabular}

${ }^{\text {a }}$ PGE means phloroglucinol equivalents. Different letters (a, b, c, d, e) indicate significant differences at the level of $P<0.05$.

${ }^{\dagger}$ DCM, dichloromethane; EtOAc, ethyl acetate

\subsection{Instrumental Analysis Data of the Isolated Compounds}

In order to elucidate the deodorizing compounds from E. bicyclis, the EtOAc-soluble extract was subjected to open column chromatography on sephadex LH-20 and LiChroprep RP-18 column. Collectively, we isolated three compounds from the EtOAc-soluble extract. The structural analysis using NMR and FAB-MS revealed the three compounds were to be eckol (1), dioxinodehydroeckol (2), and dieckol (3) (Figure 1).<smiles>Oc1cc(O)cc(Oc2c(O)cc(O)c3c2Oc2c(O)cc(O)cc2O3)c1</smiles><smiles>Oc1cc(O)c2oc3cc(O)c4oc5cc(O)cc(O)c5oc4c3oc2c1</smiles>

1

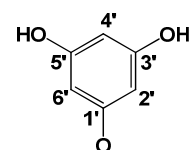

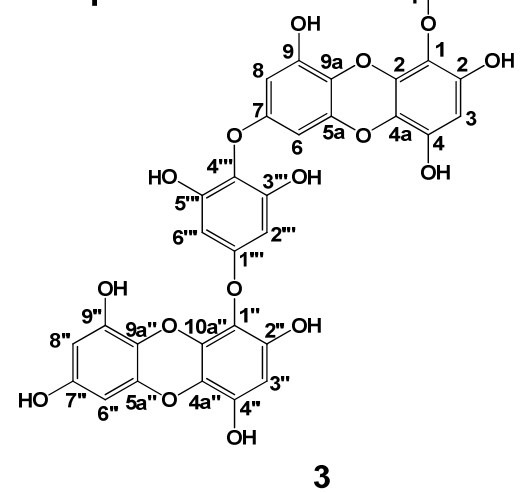

Figure 1. Structures of isolated compounds 1-3 from Eisenia bicyclis 
Compound 1 (eckol): pale brown powder, $\mathrm{C}_{18} \mathrm{H}_{12} \mathrm{O}_{9}$. FAB-MS $(m / z) 373[\mathrm{M}+\mathrm{H}]^{+}{ }^{1} \mathrm{H}-\mathrm{NMR}$ (DMSO- $d_{6}, 600 \mathrm{MHz}$ ) $\delta: 9.46(1 \mathrm{H}, \mathrm{s}, \mathrm{OH}-9), 9.41(1 \mathrm{H}, \mathrm{s}, \mathrm{OH}-4), 9.14(2 \mathrm{H}, \mathrm{s}, \mathrm{OH}-2,7), 9.11\left(2 \mathrm{H}, \mathrm{s}, \mathrm{OH}-3^{\prime}, 5^{\prime}\right), 6.14(1 \mathrm{H}, \mathrm{s}, \mathrm{H}-3), 5.96$ $(1 \mathrm{H}, \mathrm{d}, J=2.4 \mathrm{~Hz}, \mathrm{H}-8), 5.80(1 \mathrm{H}, \mathrm{d}, J=1.8 \mathrm{~Hz}, \mathrm{H}-6), 5.79\left(1 \mathrm{H}, \mathrm{d}, \mathrm{J}=3.0 \mathrm{~Hz}, \mathrm{H}-4^{\prime}\right), 5.72(2 \mathrm{H}, \mathrm{d}, J=1.8 \mathrm{~Hz}$, H-2', $\left.6^{\prime}\right) .{ }^{13} \mathrm{C}-\mathrm{NMR}$ (DMSO- $\left.d_{6}, 150 \mathrm{MHz}\right) \delta: 160.6\left(\mathrm{C}-1^{\prime}\right), 159.0\left(\mathrm{C}-3^{\prime}, 5^{\prime}\right), 153.2(\mathrm{C}-7), 146.3(\mathrm{C}-9), 146.1(\mathrm{C}-2)$, 142.8 (C-5a), 142.1 (C-4), 137.4 (C-10a), 123.4 (C-1), 122.9 (C-9a), 122.5 (C-4a), 98.7 (C-8), 98.4 (C-3), 96.4 (C-4'), 93.9 (C-2'), 93.8 (C-6), 93.7 (C-6').

Compound 2 (dioxinodehydroeckol): pale brown powder, $\mathrm{C}_{18} \mathrm{H}_{10} \mathrm{O}_{9}$. FAB-MS $(m / z) 371[\mathrm{M}+\mathrm{H}]^{+}{ }^{1} \mathrm{H}-\mathrm{NMR}$ (DMSO- $\left.d_{6}, 600 \mathrm{MHz}\right) \delta: 9.73(1 \mathrm{H}, \mathrm{s}, \mathrm{OH}-1), 9.59(1 \mathrm{H}, \mathrm{s}, \mathrm{OH}-9), 9.56(1 \mathrm{H}, \mathrm{s}, \mathrm{OH}-6), 9.24(1 \mathrm{H}, \mathrm{s}, \mathrm{OH}-3), 9.23$ $(1 \mathrm{H}, \mathrm{s}, \mathrm{OH}-11), 6.10(1 \mathrm{H}, \mathrm{s}, \mathrm{H}-7), 6.04(1 \mathrm{H}, \mathrm{d}, J=2.7 \mathrm{~Hz}, \mathrm{H}-2), 6.01(1 \mathrm{H}, \mathrm{d}, J=2.7 \mathrm{~Hz}, \mathrm{H}-10), 5.84(1 \mathrm{H}, \mathrm{d}, J=$ $2.7 \mathrm{~Hz}, \mathrm{H}-4), 5.82(1 \mathrm{H}, \mathrm{d}, J=2.7 \mathrm{~Hz}, \mathrm{H}-12) .{ }^{13} \mathrm{C}-\mathrm{NMR}$ (DMSO- $\left.d_{6}, 150 \mathrm{MHz}\right) \delta: 153.3(\mathrm{C}-3), 153.0(\mathrm{C}-11)$, 146.3 (C-1), 146.1 (C-9), 142.1 (C-4a), 141.7 (C-12a), 140.1 (C-6), 137.2 (C-7a), 131.6 (C-13b), 125.9 (C-5a), 122.6 (C-8a), 122.4 (C-13a), 122.2 (C-14a), 98.8 (C-2, 10), 97.5 (C-7), 93.9 (C-4, 12).

Compound 3 (dieckol): pale brown powder, $\mathrm{C}_{36} \mathrm{H}_{22} \mathrm{O}_{18}$. FAB-MS $(m / z) 743[\mathrm{M}+\mathrm{H}]^{+1} \mathrm{H}-\mathrm{NMR}$ (DMSO- $d_{6}, 600$ MHz) $\delta: 9.65(1 \mathrm{H}, \mathrm{s}, \mathrm{OH}-9), 9.55\left(1 \mathrm{H}, \mathrm{s}, \mathrm{OH}-9^{\prime \prime}\right), 9.45\left(1 \mathrm{H}, \mathrm{s}, \mathrm{OH}-4^{\prime \prime}\right), 9.40(1 \mathrm{H}, \mathrm{s}, \mathrm{OH}-4), 9.31\left(2 \mathrm{H}, \mathrm{s}, \mathrm{OH}-3^{\prime \prime \prime}\right.$, 5 ), $9.23\left(1 \mathrm{H}, \mathrm{s}, \mathrm{OH}-2^{\prime \prime}\right), 9.18(1 \mathrm{H}, \mathrm{s}, \mathrm{OH}-2), 9.17\left(1 \mathrm{H}, \mathrm{s}, \mathrm{OH}-7^{\prime \prime}\right), 9.10\left(2 \mathrm{H}, \mathrm{s}, \mathrm{OH}-3^{\prime}, 5^{\prime}\right), 6.16\left(1 \mathrm{H}, \mathrm{s}, \mathrm{H}-3^{\prime \prime}\right)$, 6.14(1H, s, H-3), $6.02(1 \mathrm{H}, \mathrm{d}, J=3.0 \mathrm{~Hz}, \mathrm{H}-8), 5.99\left(1 \mathrm{H}, \mathrm{d}, J=3.0 \mathrm{~Hz}, \mathrm{H}-8^{\prime \prime}\right), 5.95\left(2 \mathrm{H}, \mathrm{s}, \mathrm{H}-2^{\prime \prime \prime}, 6^{\prime \prime \prime}\right), 5.82(1 \mathrm{H}$, d, $J=3.0 \mathrm{~Hz}, \mathrm{H}-6), 5.81\left(1 \mathrm{H}, \mathrm{d}, J=3.0 \mathrm{~Hz}, \mathrm{H}-6^{\prime \prime}\right), 5.80\left(1 \mathrm{H}, \mathrm{d}, J=1.8 \mathrm{~Hz}, \mathrm{H}-4^{\prime}\right), 5.72\left(2 \mathrm{H}, \mathrm{d}, J=1.8 \mathrm{~Hz}, \mathrm{H}-2^{\prime}\right.$, $\left.6^{\prime}\right) .{ }^{13} \mathrm{C}-\mathrm{NMR}\left(\mathrm{DMSO}-d_{6}, 150 \mathrm{MHz}\right) \delta$ : $160.2\left(\mathrm{C}-1^{\prime}\right), 158.7\left(\mathrm{C}-3^{\prime}\right) 158.6\left(\mathrm{C}-5^{\prime}\right), 155.8\left(\mathrm{C}-1^{\prime \prime \prime}\right), 154.2(\mathrm{C}-7), 153.0$ (C-7"), 151.1 (C-3"', 5"'), 146.0 (C-2, 9"), 145.8 (C-2", 9), 142.5 (C-5a"), 142.3 (C-5a), 141.9 (C-4"), 141.8 (C-4), 137.2 (C-10a), 137.0 (C-10a"), 124.2 (C-4"'), 124.0 (C-9a), 123.2 (C-4a), 123.1 (C-4a"), 122.6 (C-9a"), 122.2 (C-1, 1"), 98.3 (C-3), 98.2 (C-3"), 98.0 (C-8, 8"), 96.1 (C-4'), 94.4 (C-2"', 6"'), 93.8 (C-6"), 93.6 (C-2', 6'), 93.5 (C-6).

\subsection{The Identification and Deodorizing Activity of Active Components}

Three isolated deodorizing compounds from EtOAc-soluble fraction against methyl mercaptan were shown in Table 3. The results revealed that compound $3\left(\mathrm{IC}_{50}\right.$ value of $\left.26.71 \pm 4.16 \mu \mathrm{g} \mathrm{mL}^{-1}\right)$ shows the highest deodorizing activity, followed by compound 2 ( $\mathrm{IC}_{50}$ value of $\left.40.57 \pm 0.63 \mu \mathrm{g} \mathrm{mL} \mathrm{L}^{-1}\right)$ and compound $\mathbf{1}\left(\mathrm{IC}_{50}\right.$ value of $43.62 \pm 1.52 \mu \mathrm{g} \mathrm{mL}^{-1}$ ). In addition, as the concentrations of compound $\mathbf{1}, \mathbf{2}$, and $\mathbf{3}$ increased, the deodorizing activities increased simultaneously. Thus these phlorotannins showed dose-dependent deodorizing activity (Figure 2).

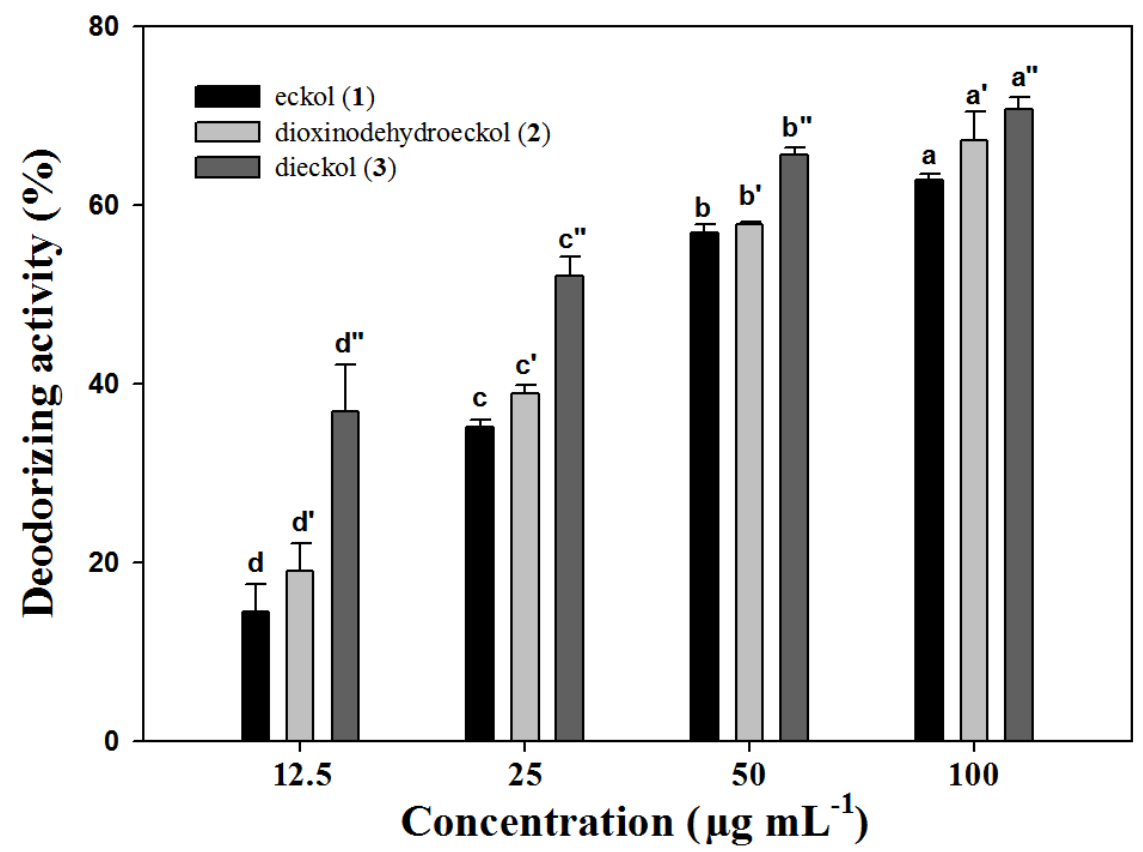

Figure 2. Inhibitory effect of eckol (1), dioxinodehydroeckol (2), and dieckol (3) on deodorizing activity. Different letters indicate significantly different values $(P<0.05)$ 
Table 3. Deodorizing activities of compounds 1-3 isolated from Eisenia bicyclis

\begin{tabular}{ll}
\hline Components & $\mathrm{IC}_{50}{ }^{*}$ value $\left(\mu \mathrm{g} \mathrm{mL}^{-1}\right)$ \\
\hline Eckol (1) & $43.62 \pm 1.52^{\mathrm{a}}$ \\
Doxinodehydroeckol (2) & $40.57 \pm 0.63^{\mathrm{a}}$ \\
Dieckol (3) & $26.71 \pm 4.16^{\mathrm{b}}$ \\
Sodium copper chlorophylline & $605.13 \pm 17.64$
\end{tabular}

${ }^{*} \mathrm{IC}_{50}$ value was defined as the concentration of inhibitor required to inhibit $50 \%$ of deodorizing activity. Different letters $(\mathrm{a}, \mathrm{b})$ indicate significant differences at the level of $P<0.05$.

\section{Discussion}

VSCs in the mouth consists of hydrogen sulphide, methyl mercaptan and dimethyl sulphide with a unpleasant odor (Sharma et al., 2011). In the above studies, the deodorizing effect was evaluated in the generation of methyl mercaptan, a malodor arising from the oral malodorous breath (Tamaki et al., 2007).

Epigallocatechin gallate from green tea, which was known for its potent effect in deodorizing activity, showed $\mathrm{IC}_{50}$ at $10 \mathrm{mmol} \mathrm{mL}^{-1}$ (Yasuda et al., 1995). Variegatic acid derived from Boletus subvelutipes showed at $2 \mathrm{mmol}$ $\mathrm{mL}^{-1}$ (Negishi et al., 2000). Kita et al. (1990) reported inhibitory effect against methyl mercaptan of flavonoid from a terrestrial plant. Urabe et al. (1999) also reported inhibitory effect against methyl mercaptan of the extracts from Taraxacum spp., Sonchus asper, Cirsium japonicum, Sasa veitchii, Equisetum arvense, and Houttuynia cordata. Furthermore, Negishi and Negishi (1999) have reported that Malus pumila, Pyrus pyrifolia var., Eriobotrya japonica, and Prunus persica extracts have a deodorizing activity against methyl mercaptan (Lee et al., 1999; Lee et al., 2001).

In Table 3, compound 3, which contains the highly polymerized phloroglucinol, showed higher deodorizing activity than compound $\mathbf{1}$ and $\mathbf{2}$. The function mechanism of the deodorizing effect has not been cleared, the conversion of hydroxy group into quinone in lignins might be expected for the function mechanism of the deodorizing effect (Hiramoto et al., 2006). Compound 3 was estimated to possess about 22 times more strong deodorizing activity than sodium copper chlorophyllin. For more than 50 years, sodium copper chlorophyllin as positive control in this study has been used in supplements and as an over-the-counter drug used to reduce odor without any serious side effects (Higdon, 2007). However, sodium copper chlorophyll has occasionally been reported to cause the diarrhea related to oral chlorophyllin use (Shiomi et al., 2010).

Moreover, the oral administration of the phlorotannins at a dosage rate of $170-1,500 \mathrm{mg} \mathrm{kg}^{-1} \mathrm{bw} \mathrm{day}^{-1}$ for 14 days in mice observed no any cytotoxic effect (Ahn et al., 2004). Since phlorotannins from E. cava has been approved by the U.S. Food and Drug Administration as a new dietary ingredient (FDA-1995-S-0039-0176), phlorotannins from E. bicyclis are also expected to be potential candidates for halitosis control as a usage of toothpaste, chewing gum, and mouthwash without side effect. Therefore, these compounds (1-3) may safe and efficient deodorizing agents for treating malodor.

In conclusion, we obtained active compounds $\mathbf{1}, \mathbf{2}$, and $\mathbf{3}$ from E. bicyclis against methyl mercaptan, main cause of bad breath. The results of this study are expected and contributed to develop safe and efficacious substances for the food and pharmaceutical industries.

\section{Acknowledgment}

This research was supported by 2011 High Value Added Food Industry Professional Human Resources Development Project, Ministry for Food, Agriculture, Forestry and Fisheries, Republic of Korea.

\section{References}

Ahn, M. J., Yoon, K. D., Min, S. Y., Lee, J. S., Kim, J. H., Kim, T. G., ... Kim, J. (2004). Inhibition of HIV-1 reverse transcriptase and protease by phlorotannins from the brown alga Ecklonia cava. Biological \& Pharmaceutical Bulletin, 27, 544-547. http://dx.doi.org/10.1248/bpb.27.544

Ali, V., \& Nozaki, T. (2007). Current therapeutics, their problems, and sulfur-containing-amino-acid metabolism as a novel target against infections by "amitochondriate" protozoan parasites. Clinical Microbiology Reviews, 20, 164-187. http://dx.doi.org/ 10.1128/CMR.00019-06

Cho, S. M., Han, D. S., Kim, S. B., Yoon, M. S., Yang, H. J., Jin, Y. H., ... Shimizu, M. (2012). Depressive effects on the central nervous system and underlying mechanism of the enzymatic extract and its 
phlorotannin-rich fraction from Ecklonia cava edible brown seaweed. Bioscience, Biotechnology, and Biochemistry, 76, 163-168. http://dx.doi.org/10.1271/bbb.110702

Dodds, M. W. J., Maxwell, J. R., Greenberg, M. J., \& Tian, M. (2009). Vehicles for oral care with magnolia bark extract. U.S. Patent No. 7,592,025 B2.

Du, X., Whitaker, V., \& Rouseff, R. (2012). Changes in strawberry volatile sulfur compounds due to genotype, fruit maturity and sample preparation. Flavour and Fragrance Journal (In press). http://dx.doi.org/10.1002/ffj.3107

Eom, S. H., Kang, Y. M., Park, J. H., Yu, D. U., Jeong E. T., Lee, M. S., \& Kim, Y. M. (2011a). Enhancement of polyphenol content and antioxidant activity of brown alga Eisenia bicyclis extract by microbial fermentation. Fisheries and Aquatic Sciences, 14, 192-197. http://dx.doi.org/10.5657/FAS.2011.0192

Eom, S. H., Lee, M. S., Lee, E. W., Kim, Y. M., \& Kim, T. H. (2012a). Pancreatic lipase inhibitory activity of phlorotannins isolated from Eisenia bicyclis. Phytotherapy Research (In press). http://dx.doi.org/10.1002/ptr.4694

Eom, S. H., Lee, S. H., Yoon, N. Y., Jung, W. K., Jeon, Y. J., Kim, S. K., ... Kim, Y. M. (2012b). $\alpha$-Glucosidaseand $\alpha$-amylase-inhibitory activities of phlorotannins from Eisenia bicyclis. Journal of the Science of Food and Agriculture, 92, 2084-2090. http://dx.doi.org/10.1002/jsfa.5585

Eom, S. H., Park, J. H., Yu, D. U., Choi, J. I., Choi, J. D., Lee, M. S., \& Kim, Y. M. (2011b). Antimicrobial activity of brown alga Eisenia bicyclis against methicillin-resistant Staphylococcus aureus. Fisheries and Aquatic Sciences, 14, 251-256. http://dx.doi.org/10.5657/FAS.2011.0251

Gnanasekhar, J. D. (2007). Aetiology, diagnosis and management of halitosis: a review. Periodontal Practice Today, 4, 203-214. Retrieved from http://perio.quintessenz.de/perio_2007_03_s0203.pdf

Higdon, J. (2007). Chlorophyll and chlorophyllin: An evidence-based approach to dietary phytochemicals (pp. 62-67). New York, NY: Thieme Medical Publishers Inc. http://dx.doi.org/10.1177/1559827607308566

Hiramoto, T., Mishima, Y., Yamamoto, T., Hansen, T. T., \& Abe, K. (2006). Deodorant composition. U.S. Patent No. 0,239,939.

Hiramoto, T., Saiki, K., \& Okazaki, T. (2001). Deodorant composition. U.S. Patent No. 6,294,161.

Hughes, F. J., \& McNab, R. (2008). Oral malodor-a review. Archives of Oral Biology, 53(Suppl), S1-S7. http://dx.doi.org/10.1016/S0003-9969(08)70002-5

Jeong, E. S., Yoon, Y. H., \& Kim, J. K. (2009). Contrasting correlation in the inhibition response of ADP-induced platelet aggregation and the anti-coagulant activities of algal fucoidans derived from Eisenia bicyclis and Undaria pinnatifida sporophylls (Mekabu). Fisheries and Aquatic Sciences, 12, 194-202.

Kang, H. S., Chung, H. Y., Jung, J. H., Son, B. W., \& Choi, J. S. (2003). A new phlorotannin from the brown alga Ecklonia stolonifera. Chemical \& Pharmaceutical Bulletin, 51, 1012-1014. http://dx.doi.org/10.1248/cpb.51.1012

Kang, H. S., Chung, H. Y., Kim, J. Y., Son, B. W., Jung, H. A., \& Choi, J. S. (2004). Inhibitory phlorotannin from the edible brown alga Ecklonia stolonifera on total reactive oxygen species (ROS) generation. Archives of Pharmacal Research, 27, 194-198. http://dx.doi.org/10.1007/BF02980106

Kang, J. Y, Choi, J. S., Park, N. G., Ahn, D. H., \& Hong, Y. K. (2012). In vivo antipyretic, analgesic, and anti-inflammatory activities of the brown alga Ecklonia cava extracts in mice. Fisheries and Aquatic Sciences, 15, 73-76. http://dx.doi.org/10.5657/FAS.2012.0073

Kang, K. A., Lee, K. H., Chae, S., Koh, Y. S., Yoo, B. S., Kim, J. H., .. \& Hyun, J. W. (2005). Triphlorethol-A from Ecklonia cava protects V79-4 lung fibroblast against hydrogen peroxide induced cell damage. Free Radical Research, 39, 883-892. http://dx.doi.org/10.1080/10715760500161165

Kang, K. A., Lee, K. H., Park, J. W., Lee, N. H., Na, H. K., Surh, Y. J., You, H. J., Chung, M. H., \& Hyun, J. W. (2007). Triphlorethol-A induces heme oxygenase-1 via activation of ERK and NF-E2 related factor 2 transcription factor. FEBS Letters, 581, 2000-2008. http://dx.doi.org/10.1016/j.febslet.2007.04.022

Kim, J. G., Kim, Y. J., Yoo, S. H., Lee, S. J., Chung, J. W., Kim, M. H., ... Hahm, K. B. (2010). Halimeter ppb levels as the predictor of erosive gastroesophageal reflux disease. Gut and Liver, 4, 320-325. http://dx.doi.org/10.5009/gnl.2010.4.3.320 
Kim, M. M., Ta, Q. V., Mendis, E., Rajapakse, N., Jung, W. K., Byun, H. G., ... Kim, S. K. (2006). Phlorotannins in Ecklonia cava extract inhibit matrix metalloproteinase activity. Life Sciences, 79, 1436-1443. http://dx.doi.org/10.1016/j.lfs.2006.04.022

Kim, S. K., Ravichandran, Y. D., Khan, S. B., \& Kim, Y. T. (2008). Prospective of the cosmeceuticals derived from marine organisms. Biotechnology and Bioprocess Engineering, 13, 511-523. http://dx.doi.org/10.1007/s12257-008-0113-5

Kita, N., Fujimoto, K., Nakajima, I., Hayashi, R., \& Shibuya, K. (1990). Screening test for deodorizing substances from marine algae and identification of phlorotannins as the effective ingredients in Eisenia bicyclis. Journal of Applied Phycology, 2, 155-162. http://dx.doi.org/10.1007/BF00023377

Lee, D. S., Kim, S. B., Kim, T. J., Kim, J. H., Ji, C. I., \& Park, J. H. (1999). Deodorant effect of marine algae extracts on halitosis. Bulletin of National Fisheries Research and Development Institute, 57, 195-201.

Lee, D. S., Kim, S. B., Kim, T. J., Kim, J. H., Min, J. H., \& Park, J. H. (2000). Factors of why Eisenia bicyclis extracts counteract halitosis. Bulletin of National Fisheries Research and Development Institute, 58, 163-167.

Lee, D. S., Kim, T. J., Kim, J. H., Kim, S. B., Cho, S. W., Lim, C. W., \& Min, J. G. (2001). Effect of Eisenia bicyclis extracts on the growth and glucosyltransferase activity of Streptococcus mutans. Bulletin of National Fisheries Research and Development Institute, 59, 171-176.

Li, Y., Qian, Z. J., Ryu, B. M., Lee, S. H., Kim, M. M., \& Kim, S. K. (2009). Chemical components and its antioxidant properties in vitro: An edible marine brown alga, Ecklonia cava. Bioorganic \& Medicinal Chemistry, 17, 1963-1973. http://dx.doi.org/10.1016/j.bmc.2009.01.031

Lourith, N., \& Kanlayavattanakul, M. (2010). Oral malodour and active ingredients for treatment. International Journal of Cosmetic Science, 32, 321-329. http://dx.doi.org/10.1111/j.1468-2494.2010.00585.x

Negishi O. Negishi Y., \& Ozawa T. (2000). Enzymatic deodorization with variegatic acid from Boletus subvelutipes and its mechanism. Food Science and Technology Research, 6, 186-191. http://dx.doi.org/10.3136/fstr.6.186

Negishi, O., \& Negishi, T. (1999). Enzymatic deodorization with raw fruits, vegetables and mushrooms. Food Science and Technology Research, 5, 176-180. http://dx.doi.org/10.3136/fstr.5.176

Okada, Y., Ishimaru, A., Suzuki, R., \& Okuyama, T. (2004). A new phloroglucinol derivative from the brown alga Eisenia bicyclis: potential for the effective treatment of diabetic complications. Journal of Natural Products, 67, 103-105. http://dx.doi.org/10.1021/np030323j

Ragan, M. A., \& Glombitza, K. W. (1986). Phlorotannins, brown algal polyphenols. Progress in Phycological Research, 4, 129-241.

Richter, J. T. (1996). Diagnosis and treatment of halitosis. Compendium of Continuing Education in Dentistry, 17, 370-388.

Sanz, M., Roldán, S., \& Herrera, D. (2001). Fundamentals of breath malodour. The journal of contemporary dental practice, 4, 1-17. Retrieved from http://www.verifresh.com/JCDP_Bad_Breath_Info.pdf

Sharma, S., Shankar, T. P., \& Koirala, B. (2011). Halitosis: a serious social problem. Health Renaissance, 9 , 106-111. http://dx.doi.org/10.3126/hren.v9i2.4983

Shiomi, T., Okuhara, Y., Tamura, A., Tomita, K., Shigematsu, N., Kikuchi, H., ... Tomita, F. (2010). Use of difructose anhydride-containing composition. U.S. Patent No. US 7,964,581

Tamaki, K., Tamaki, T., \& Yamazaki, T. (2007). Studies on the deodorization by mushroom (Agaricus bisporus) extract of garlic extract-induced oral malodor. Journal of Nutritional Science and Vitaminology, 53, 277-286. http://dx.doi.org/10.3177/jnsv.53.277

Tanabe, S., Desjardins, J., Bergeron, C., Gafner, S., Villinski, J. R., \& Grenie, D. (2012). Reduction of bacterial volatile sulfur compound production by licoricidin and licorisoflavan A from licorice. Journal of Breath Research, 6, 016006. http://dx.doi.org/10.1088/1752-7155/6/1/016006

Tokita, F., Ishikawa, M., Shibuya, K., Koshimizu, M., \& Abe, R. (1984). Deodorizing activity of some plant extracts against methyl mercaptan. Nippon Nogeikagaku Kaishi, 58, 585-589.

Urabe, K., Nadamoto, T., Kawamura, M., \& Yasumoto, K. (1999). Deodorization activity of wild grasses against methyl mercaptan. Japan Society of Nutrition and Food Science, 46, 484-486. 
Waterman, P. G., \& Mole, S. (1994). Analysis of phenolic plant metabolites (pp 83-91). Oxford, UK: Blackwell Scientific Publications.

Yoon, N. Y., Chung, H. Y., Kim, H. R., \& Choi, J. S. (2008). Acetyl- and butyrylcholinesterase inhibitory activities of sterols and phlorotannins from Ecklonia stolonifera. Fisheries Science, 74, $200-207$. http://dx.doi.org/10.1111/j.1444-2906.2007.01511.x

Yoon, N. Y., Lee, S. H., Wijesekara, I., \& Kim, S. K. (2011). In vitro and intracellular antioxidant activities of brown alga Eisenia bicyclis. Fisheries and Aquatic Sciences, 14, 179-185. http://dx.doi.org/10.5657/FAS.2011.0179

Youngnak-Piboonratanakit, P., \& Vachirarojpisan, T. (2010). Prevalence of self-perceived oral malodor in a group of thai dental patients. Journal of Dentistry of Tehran University of Medical Sciences, 7, $196-204$. Retrieved from http://journals.tums.ac.ir/abs/17639

Zou, Y., Qian, Z. J., Li, Y., Kim, M. M., Lee, S. H., \& Kim, S. K. (2008). Antioxidant effects of phlorotannins isolated from Ishige okamurae in free radical mediated oxidative systems. Journal of Agricultural and Food Chemistry, 56, 7001-7009. http://dx.doi.org/10.1021/jf801133h 